ANL/ACL-99/2

\author{
ARGONNE NATIONAL LABORATORY \\ 9700 South Cass Avenue \\ Argonne, IL 60439-4837
}

\title{
ANALYTICAL CHEMISTRY LABORATORY \\ Progress Report for FY 1999
}

Prepared by:

D. W. Green, Manager

A. S. Boparai, Group Leader

D. L. Bowers, Group Leader

D. G. Graczyk, Group Leader

with contributions from ACL Staff

Analytical Chemistry Laboratory

Chemical Technology Division

December 1999 
Reports for FY 1984 through FY 1998 are

ANL/ACL-85-1 (March 1985)

ANL/ACL-85-4 (December 1985)

ANL/ACL-86-2 (November 1986)

ANL/ACL-87-2 (December 1987)

ANL/ACL-88-1 (December 1988)

ANL/ACL-89/6 (December 1989)

ANL/ACL-90/2 (December 1990)

ANL/ACL-91/1 (December 1991)

ANL/ACL-92/4 (December 1992)

ANL/ACL-93/2 (December 1993)

ANL/ACL-94/4 (December 1994)

ANL/ACL-95/5 (December 1995)

ANL/ACL-96/6 (December 1996)

ANL/ACL-97/5 (December 1997)

ANL/ACL-98/2 (December 1998) 


\section{DISCLAIMER}

This report was prepared as an account of work sponsored by an agency of the United States Government. Neither the United States Government nor any agency thereof, nor any of their employees, make any warranty, express or implied, or assumes any legal liability or responsibility for the accuracy, completeness, or usefulness of any information, apparatus, product, or process disclosed, or represents that its use would not infringe privately owned rights. Reference herein to any specific commercial product, process, or service by trade name, trademark, manufacturer, or otherwise does not necessarily constitute or imply its endorsement, recommendation, or favoring by the United States Government or any agency thereof. The views and opinions of authors expressed herein do not necessarily state or reflect those of the United States Government or any agency thereof. 


\section{DISCLAIMER}

Portions of this document may be illegible in electronic image products. Images are produced from the best available original document. 


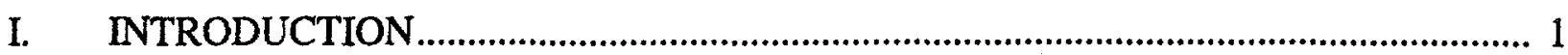

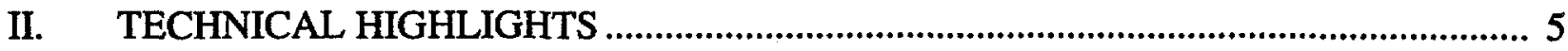

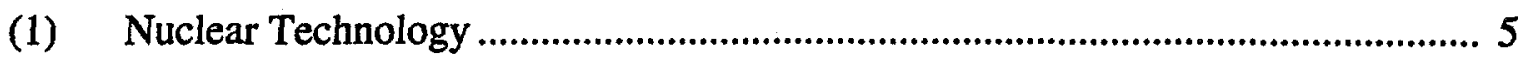

(2) Measurement of Lithium Metal Dissolved in Lithium Chloride/Lithium Oxide Molten Salts ...................................................................................................... 5

(3) Performance Demonstration Program for the WIPP Transuranic Solidified Waste Characterization Program.................................................................................. 6

(4) Stibine Evolution from Lithium Antimonide ............................................................ 7

(5) Long-Term Performance of Fuel Reforming Catalysts......................................... 8

(6) Performance Demonstration Program for Analysis of Simulated Headspace Gases for the WIPP Project.................................................................................. 9

(7) Analysis of Corrosion Material on Ion Pump Ceramic Insulators for ................... 9 Fermilab

(8) Multiagency Radiochemistry Laboratory Analytical Procedures (MARLAP)

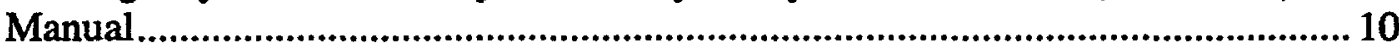

(9) The Department of Energy's National Analytical Management Program: Projects at Argonne National Laboratory................................................................. 11

(10) Preparation of Uranium Standard Near Natural ${ }^{236}$ U Concentration ..................... 13

(11) Sister Laboratory Agreement with Costa Rica....................................................... 14

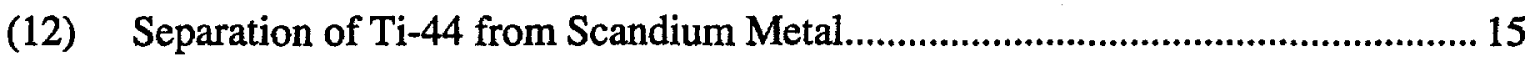

(13) Preparation of Osmium-189 Targets for Photon Excitation Studies .................... 16

(14) Radiological Analysis Support for U.S. EPA Region V ....................................... 17

(15) Measurement of Carbon in Lithium Aluminate Ceramics .................................... 19 


\section{TABLE OF CONTENTS (Contd)}

Page

(16) Microwave-Accelerated Acid Dissolution of Lithium Aluminate .......................... 20

(17) High-Precision Assay of Lithium and Aluminum by ICP/AES............................21

(18) Effect of Aluminum on Lithium Isotopic Analysis by Thermal Ionization Mass Spectrometry

(19) Method for Determining Halide Impurities in Refractory Materials .....................24

(20) Assembled Chemical Weapons Assessment Program ............................................ 25

(21) Characterization of Unidentified Waste Materials.................................................26

(22) Quality Assurance Laboratory Support to the U.S. Army Corps of Engineers

(23) Data Validation for the U.S. Army Corps of Engineers.......................................29

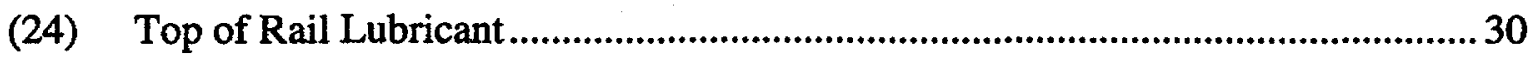

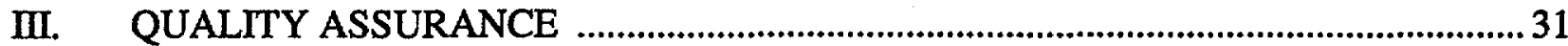

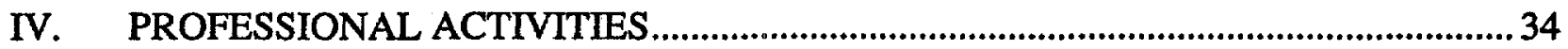

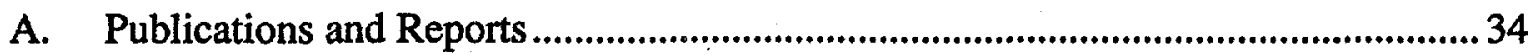

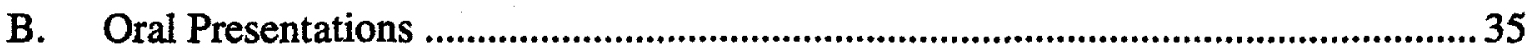

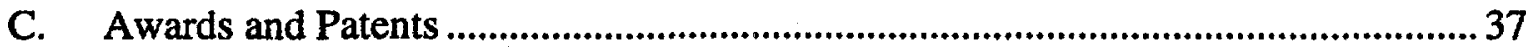

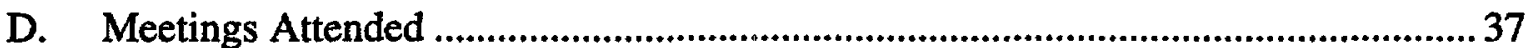

E. Professional Organizations and Activities ................................................................38

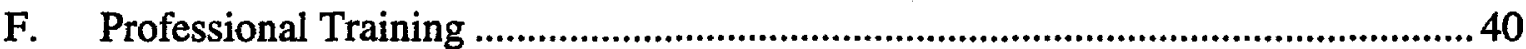

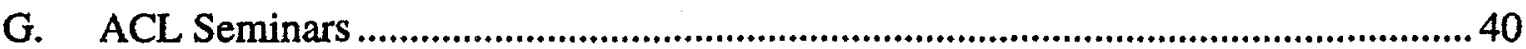




\section{NOMENCLATURE}

$\begin{array}{ll}\text { ACL } & \text { Analytical Chemistry Laboratory } \\ \text { ACWA } & \text { Assembled Chemical Weapons Assessment } \\ \text { ANL } & \text { Argonne National Laboratory } \\ \text { APS } & \text { Advanced Photon Source } \\ \text { ATLAS } & \text { Argonne Tandem-Linear Accelerator System } \\ \text { CAMDS } & \text { Chemical Agent Munitions Disposal System } \\ \text { CLP } & \text { Contract Laboratory Program } \\ \text { CMT } & \text { Chemical Technology Division } \\ \text { CVAA } & \text { cold vapor atomic absorption } \\ \text { DCD } & \text { Deseret Chemical Depot } \\ \text { DEMSAR } & \text { Directory of EM Sampling and Analysis Resources } \\ \text { DOD } & \text { Department of Defense } \\ \text { DOE } & \text { Department of Energy } \\ \text { EDS } & \text { energy-dispersive spectrometry } \\ \text { EM } & \text { Environmental Management } \\ \text { EPA } & \text { Environmental Protection Agency } \\ \text { FTIR } & \text { Fourier transform infrared } \\ \text { FUSRAP } & \text { Formerly Utilized Sites Remedial Action } \\ \text { FY } & \text { fiscal year } \\ \text { GC/MS } & \text { gas chromatography/mass spectrometry } \\ \text { GPE } & \text { General Purpose Equipment fund } \\ \text { IAG } & \text { Interagency Agreement } \\ \text { IC } & \text { ion chromatography } \\ \text { ICDD } & \text { International Center for Diffraction Data } \\ \text { ICP/AES } & \text { inductively coupled plasma/atomic emission spectrometry } \\ \text { ICP/MS } & \text { inductively coupled plasma/mass spectrometry } \\ \text { IPEP } & \text { Integrated Performance Evaluation Program } \\ \text { MARLAP } & \text { Multiagency Radiochemistry Laboratory Analytical Procedures Manual } \\ \text { MS } & \text { mass spectrometry } \\ \text { NAMP } & \text { National Analytical Management Program } \\ \text { NEET } & \text { Nuclear Excitation by Electronic Transition } \\ \text { NRC } & \text { Nuclear Regulatory Commission } \\ \text { NSTS } & \text { National Sample Tracking System } \\ \text { PDP } & \text { Performance Demonstration Program } \\ \text { PE } & \text { performance evaluation } \\ \text { PFS-WMO } & \text { Plant Facilities and Services-Waste Management Operations } \\ \text { PHY } & \text { Physics Division } \\ \text { QA } & \text { quality assurance } \\ \text { QC } & \text { quality control } \\ \text { RCRA } & \text { Resource Conservation and Recovery Act } \\ \text { R\&D } & \text { research and development } \\ \text { RSD } & \text { relative standard deviation } \\ \text { SAS } & \text { special analytical services } \\ & \end{array}$


NOMENCLATURE (contd)

SEM

SOP

TIMS

TLV

TRU

USACE

VOC

WIPP

WP

WS

WWW

XRD scanning electron microscopy

standard operating procedure

thermal ionization mass spectrometry

Threshold Limit Value

transuranic

U.S. Army Corps of Engineers

volatile organic compound

Waste Isolation Pilot Plant

Water Pollution Study

Water Supply Study

World Wide Web

$\mathrm{X}$-ray diffraction 


\section{ANALYTICAL CHEMISTRY LABORATORY \\ Progress Report for FY 1999}

\section{INTRODUCTION}

This report summarizes the activities of the Analytical Chemistry Laboratory (ACL) at Argonne National Laboratory (ANL) for Fiscal Year (FY) 1999 (October 1998 through September 1999). This annual progress report, which is the sixteenth in this series for the ACL, describes effort on continuing projects, work on new projects, and contributions of the ACL staff to various programs at $\mathrm{ANL}$.

The ACL operates within the ANL system as a full-cost-recovery service center, but it has a mission that includes a complementary research and development component:

The Analytical Chemistry Laboratory will provide highquality, cost-effective chemical analysis and related technical support to solve research problems of our clients-Argonne National Laboratory, the Department of Energy, and others-and will conduct world-class research and development in analytical chemistry and its applications.

Because of the diversity of research and development (R\&D) work at ANL, the ACL handles a wide range of analytical problems. Some routine or standard analyses are done, but the ACL usually works with commercial laboratories if high-volume, production analyses are required by our clients. It is common for the ANL R\&D programs to generate unique problems that require significant development of methods and adaptation of techniques to obtain useful analytical data. Thus, much of the support work done by the ACL is very similar to applied analytical chemistry research work. 
The ACL is administratively within the Chemical Technology Division (CMT), its principal ANL client, but it provides technical support for many of the other technical divisions and programs at ANL. The ACL had three technical groups in FY 1999: Chemical Analysis, Instrumental Analysis, and Organic Analysis. Although staffing levels varied during the year, the ACL included about 20 technical staff members. (See Fig. 1.) Talents and interests of staff members cross group lines, as do many projects within the ACL.

The Chemical Analysis Group uses wet chemical and instrumental methods for elemental, compositional, and isotopic determinations in solid, liquid, and gaseous samples and provides specialized analytical services. The Instrumental Analysis Group uses nuclear counting techniques to determine the radiochemical constituents in a wide range of sample types, from environmental samples with low radioactivity to samples with high radioactivity requiring containment, and provides quality assurance support to the U.S. Department of Energy (DOE) and other clients for various kinds of analytical data. The Organic Analysis Group uses a number of complementary techniques to separate organic compounds and measure them at trace levels. Together, the ACL groups have a full range of analytical capabilities for performing inorganic, organic, and radiological analyses.

The ACL has a sample-receiving system that includes chain-of-custody procedures and allows efficient processing of environmental samples and hazardous and mixed-waste samples. The ACL also has quality assurance (QA) and quality control $(\mathrm{QC})$ systems in place to produce data packages that meet the reporting requirements of organizations such as the DOE, the U.S. Environmental Protection Agency (EPA), and the U.S. Army Corps of Engineers (USACE). Project-specific quality assurance requirements can be handled within the ACL's QA structure.

More detailed information is available through the ACL's internet Web site at http://www.cmt.anl.gov/acl/acl.htm. Topics available from the Web site include the following:

- List of all published ANL/ACL technical reports

- Major technical specialties of the ACL staff

- Advice on how to submit samples 
- The ACL Annual Reports for FY 1995 through FY 1998

The ACL has also developed this Web site for internal use: it includes the current version of all ACL standard operating procedures (SOPs) and several QA documents. With this mode of operation we help ensure the ready availability of the most recent version of each document.

A new alpha spectrometer acquisition and data handling system, which was funded by the ANL General Purpose Equipment Fund (GPE), was procured in FY 1999. Installation should be completed in early FY 2000. The new system replaces an outdated version and will have 24 detectors, versus the previous 12. The ACL's clients will benefit from lower cost, faster turnaround time, and higher accuracy as radiological measurements are done with this system. The more automated data processing software in this system allows the generation of control charts and statistical tests. A Varian Saturn 2000 ion trap mass spectrometer was also procured with GPE funds in FY 1999. This spectrometer, which includes an autosampler, was installed and is operational. It has upgraded our analytical capability for determination of semivolatile organic compounds and will allow determination of other classes of compounds that could not be easily accomplished with our existing instruments. Because of increased sensitivity, the ion trap gas chromatography/mass spectrometry (GC/MS) system will allow us to determine toxaphenes, dibenzo dioxins, dibenzo furans, and congener-specific polychlorinated biphenyls. The instrument is easily expandable to handle injections by the solid-phase micro-extraction fiber method.

The remainder of this report comprises short descriptions of the analytical work performed by the staff of the ACL in FY 1999 on selected projects. It covers only a fraction of approximately 1000 different jobs, many of which involve several samples, that the ACL receives annually. Many contributions by the ACL staff are not included because they involved generation of analytical data on only a relatively small number of samples. Despite their small scope, these analytical results often make an important contribution to the overall success of the project that received the data. These contributions to projects can easily be overlooked, but collectively they form an important part of the mission of the ACL. 
Fig. 1 Analytical Chemistry Laboratory

Organization Chart

September 1999

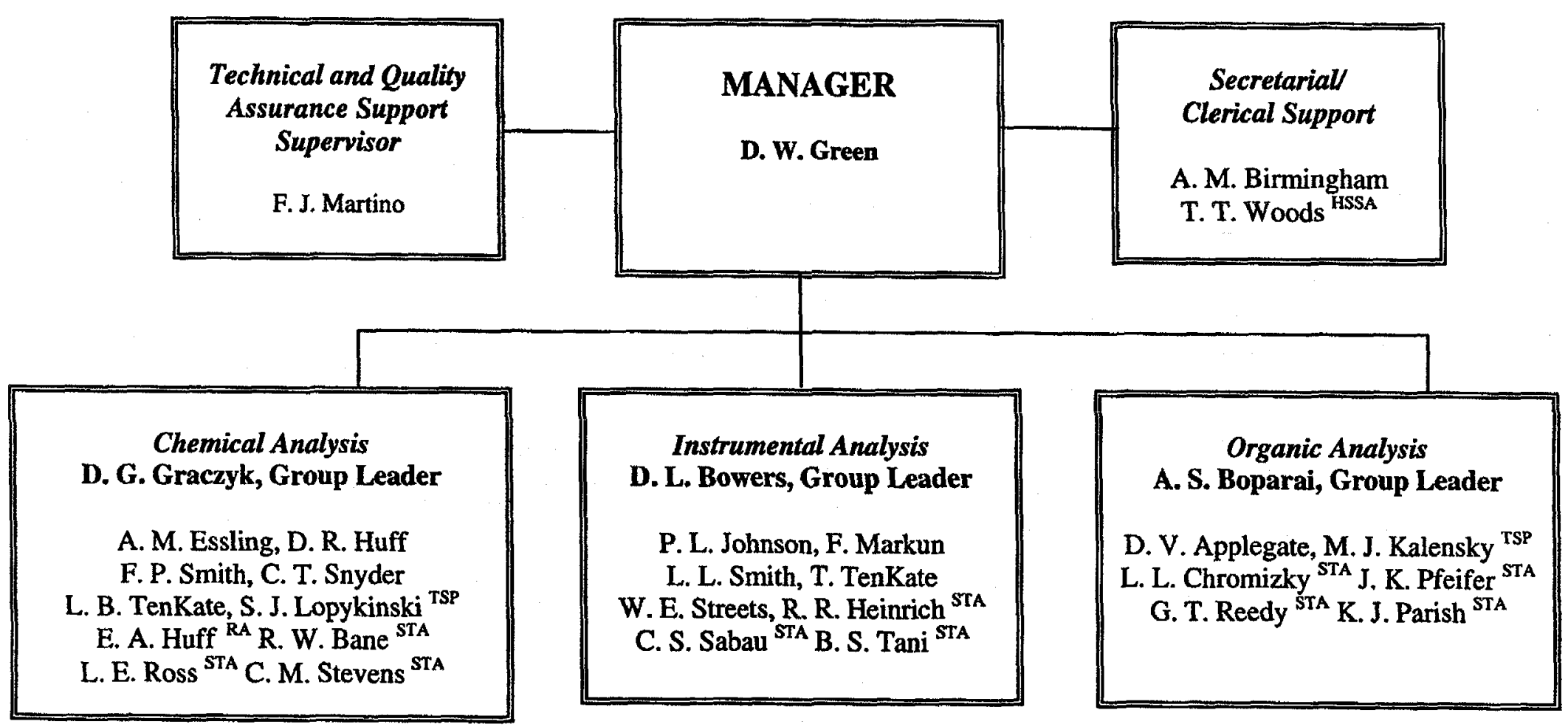

HSSA = High School Student Aide; TSP = Temporary Support Personnel; STA = Special Term Appointee; RA = Resident Associate. 


\section{TECHNICAL HIGHLIGHTS}

(1) Nuclear Technology (D.L. Bowers)

The CMT efforts in developing pyrochemical processes for actinides separation continued in FY99 with experiments using $\mathrm{Li}$ - $\mathrm{Al}$ alloys as reductants to reduce $\mathrm{UCl}_{3}, \mathrm{PuCl}_{3}$, and selected rare earth chlorides in a $\mathrm{LiCl}-\mathrm{KCl}$ electrolyte. In these tests either pure lithium or an aluminum alloy of lithium was added to the electrolyte containing the dissolved $\mathrm{UCl}_{3}, \mathrm{PuCl}_{3}$, and chlorides of $\mathrm{Ce}, \mathrm{La}, \mathrm{Pr}, \mathrm{Nd}, \mathrm{Sm}, \mathrm{Eu}$, and $\mathrm{Y}$. Samples were taken periodically during the experiments and submitted to the ACL for analysis. After these samples were dissolved, their $\mathrm{U}$, $\mathrm{Pu}$, and rare earth elemental concentrations were determined using inductively coupled plasma/atomic emission spectroscopy (ICP/AES) and inductively coupled plasma/mass spectrometry (ICP/MS), which was operated by Y. Tsai (CMT). Data from these analyses confirmed thermodynamic predictions that the concentration of these chlorides can be lowered to very low levels. Of particular interest was the finding that both $\mathrm{EuCl}_{3}$ and $\mathrm{SmCl}_{3}$ were reduced to the metal and that the $\mathrm{PuCl}_{3}$ and $\mathrm{UCl}_{3}$ were reduced to low concentrations; thus, a non-TRU salt can be obtained by this process.

(2) Measurement of Lithium Metal Dissolved in Lithium Chloride/Lithium Oxide Molten Salts (C. T. Snyder and D. G. Graczyk)

A process is being developed by $\mathrm{CMT}$, which uses lithium at $650^{\circ} \mathrm{C}$ in the presence of $\mathrm{LiCl}$ to reduce actinide oxides to the corresponding metals, producing $\mathrm{Li}_{2} \mathrm{O}$. In support of this project, a CMT researcher (K. Gourishankar) was interested in measuring the solubility of lithium metal in $\mathrm{LiCl} / \mathrm{Li}_{2} \mathrm{O}$ molten salts. The ACL contributed to this effort by measuring the quantity of lithium metal present in salt samples withdrawn from a molten salt bath as its composition was varied. Each salt sample, contained in sections of tantalum tubing, was reacted 
with water in a special apparatus designed to permit the collection and precise measurement of hydrogen gas evolved when the lithium metal reacts with water. The method used by the ACL included the addition of a known quantity of helium to the hydrogen evolution apparatus and subsequent measurement of the hydrogen-to-helium ratio by mass spectrometry (MS) to determine the quantity of hydrogen evolved. Sensitivity was easily sufficient to measure the lithium metal concentrations at levels below $0.1 \mathrm{wt} \%$ in the salt. Precision of the measurements is estimated to be about $3 \%$, relative. The results of these measurements are expected to provide data on fundamental properties that are not only applicable to the CMT process, but also of general interest to pyrometallurgical process engineers, thermodynamicists, and other scientists.

Performance Demonstration Program for the WIPP Transuranic Solidified Waste Characterization Program (A. S. Boparai and L. L. Chromizky)

The Waste Isolation Pilot Plant (WIPP) is a DOE installation designed to dispose of transuranic (TRU) waste left from the research on, and production of nuclear weapons. The WIPP site consists of large interconnecting cavities hollowed out of deep geologic salt beds approximately $600 \mathrm{~m}$ underground and is located approximately 26 miles east of Carlsbad, NM. The TRU waste destined for WIPP originated during the 1940s from the nation's nuclear weapons programs at various DOE sites. The first shipment of waste for disposal was received at the WIPP site in March 1999.

Wastes to be shipped to WIPP must first be characterized to identify any hazardous materials in the waste in addition to the radioactive constituents. As part of the WIPP TRU waste characterization program, a Performance Demonstration Program (PDP) for Resource Conservation and Recovery Act (RCRA) Constituent Analysis of Solidified Wastes (a RCRA PDP) was established in 1995. 
The purpose of the RCRA PDP is to provide data on the performance of each participating laboratory for the analysis of solidified TRU waste samples for specified metal, semivolatile and volatile organic compounds, and PCBs. The Carisbad Area Office approves laboratories that successfully analyze blind audit samples for analyzing TRU waste samples destined for WIPP.

During FY99 the ACL prepared approximately $2 \mathrm{~kg}$ each of uncemented and cemented simulated Type 1 solidified waste. The waste matrix was then supplied to a contractor selected by the PDP coordinator to spike the matrix with metal analytes. These spiked samples were checked by the contractor for homogeneity before shipment to the laboratories for analysis. The contractor also provided blind audit samples of semivolatile and volatile organic compounds that utilize a non-interfering matrix for determination of target analytes to the participating laboratories.

(4) Stibine Evolution from Lithium Antimonide (F. P. Smith and D. G. Graczyk)

Researchers in CMT (L. Leibowitz, S. McDeavitt) synthesized a batch of lithium antimonide, $\mathrm{Li}_{3} \mathrm{Sb}$, for use in experiments related to electrorefiner development. They were concerned about its potential to evolve stibine gas $\left(\mathrm{SbH}_{3}\right)$ during operations outside of the inertatmosphere glovebox where it was made. Stibine is a poisonous gas that has a Threshold Limit Value (TLV) concentration of $0.1 \mathrm{ppm}\left(0.58 \mathrm{mg}\right.$ of $\mathrm{SbH}_{3}$ per $\left.\mathrm{m}^{3}\right)$. Exposure to a concentration of $10 \mathrm{ppm}$ can be fatal. The ACL was asked to determine whether stibine is produced when the $\mathrm{Li}_{3} \mathrm{Sb}$ compound is exposed to moist air, water, or acid solution.

For these tests, we assembled a gas analysis train in a fume hood. The train consisted of a closed reaction vessel in which the lithium antimonide could be reacted under a flowing gas stream such that any stibine released would be carried into a set of gas-washing bottles 
(bubblers) filled with an absorber solution composed of $\mathrm{I}_{2}$ and $\mathrm{KI}$ in $3 \underline{\mathrm{N}}$ sulfuric acid (Holland's solution). The Holland's solution absorber was used by the ACL in the late 1970s for monitoring stibine evolution during operations with lead-acid batteries. Stibine is converted to a colored anion, $\mathrm{Sbl}_{4}^{-}$, that can be measured photometrically after the iodine in the solution is reduced with hypophosphite. No stibine was detected $(<3 \mu \mathrm{g})$ after exposing $1 \mathrm{~g}$ of $\mathrm{Li}_{3} \mathrm{Sb}$ to moist air for over two hours, but when the $1 \mathrm{~g} \mathrm{Li}_{3} \mathrm{Sb}$ was contacted with liquid water, we recovered $1.76 \mathrm{mg}$ of stibine. With $6 \underline{\mathrm{M}}$ hydrochloric acid, $1.23 \mathrm{mg} \mathrm{SbH}$ was evolved. Results from these tests contributed to the operational safety review for work with the lithium antimonide material and helped to ensure the material was handled with appropriate precautions.

Long-Term Performance of Fuel Reforming Catalysts (D. V. Applegate, A. M. Essling, F. P. Smith, C. T. Snyder, D. R. Huff, and S. J. Lopykinski)

The ACL is assisting CMT's Fuel Cell group in testing the long-term performance of several of its fuel reforming catalysts. This task required the designing and building of a new microreactor that would run safely unattended for up to 1000 hours. The microreactor allows the catalyst to reform hydrocarbon fuel (pump gasoline) at approximately $700^{\circ} \mathrm{C}$, resulting in the formation of hydrogen, carbon dioxide, and carbon monoxide. In order to evaluate the performance of the catalyst over time, an analytical system was set up to monitor the gas composition, total gas flow output pressure, and temperature in multiple ports of the apparatus. A back-up gas chromatograph (GC) was also set up to analyze the output gas for unknown compounds and to confirm the primary analytical system. The GC has a thermal conductivity detector and a mass selective detector with two different columns to look for a full suite of permanent gases and light hydrocarbon gases. The ACL has also assisted the Fuel Cell group by analyzing the inorganic composition of the catalysts both before and after the 1000 hour tests to 
help shed light on the catalyst's operation and performance. These tests included ICP/AES and ICP/MS measurements and carbon, nitrogen, and sulfur determinations.

(6) Performance Demonstration Program for Analysis of Simulated Headspace Gases for the WIPP Project (A. S. Boparai, D. V. Applegate, M. H. Vander Pol, D. G. Graczyk, and C. T. Snyder)

Headspace gas from wastes destined for WIPP must be characterized to identify nonradioactive hazardous materials, just like the solid waste material is (see Section ПI.3). Analysis is required of the headspace gas for specified volatile organic compounds and hydrogen and methane. The National TRU Program Office of the Carlsbad Area Office of DOE has established a Performance Demonstration Program (PDP) for laboratories to analyze headspace gas in waste containers that will be shipped to the WIPP site. The Carlsbad Area Office grants approval for analysis of headspace gases to laboratories that are successful in analyzing blind audit samples of simulated headspace gases. The ACL was selected as the laboratory to prepare, analyze, and distribute samples for the headspace gas PDP.

During FY99, the ACL prepared 11 sets of headspace gas samples for Cycle 13 of the PDP. Nine sets were sent to participating laboratories, one set was used for verification analysis, and one set was archived. Each set of PDP samples consisted of 6-L SUMMA canisters containing low, high, special, and duplicate mixtures of analytes. A blank containing Ultra Zero grade air was also included in the set.

(7) Analysis of Corrosion Material on Ion Pump Ceramic Insulators for Fermilab (P. L. Johnson, B. S. Tani, and D. L. Bowers)

A group at Fermilab was having a problem with the performance of conductors that interfered with the operation of one of their devices. The ACL analyzed corroded electrical conductors that were associated with the failures to determine if some unusual materials had 
formed that were causing the problem. One technique that was used was XRD using a Rigaku $\mathrm{D} / \max 2400$ vertical $\mathrm{X}$-ray diffractometer. A second technique was energy dispersive spectroscopy (EDS); it was carried out using a Noran Vantage system, which is incorporated within a JEOL JSM6400 scanning electron microscope. The objective was to determine the elemental composition of compounds that were found on the ion pump ceramics with EDS and to identity them with XRD.

Measurements with EDS showed that copper was the most abundant element. An XRD analysis of the material was compared with data provided by the International Centre for Diffraction Data (ICDD). The observed XRD pattern was consistent with copper nitrate hydroxide $\left(\mathrm{Cu}_{2}\left(\mathrm{NO}_{3}\right)(\mathrm{OH})_{3}\right.$. Materials of different colors were found on the ceramics, but copper nitrate hydroxide was the most prominent compound found in each sample.

The EDS measurements on the surface of some corroded material showed the presence of $\mathrm{C}, \mathrm{Ni}$, and $\mathrm{Cu}$, indicating that it was nickel-plated copper. Therefore, an important corrosion product (i.e., copper nitrate hydroxide) came from elemental copper that was present from the beginning in the system. Grease was applied to the connectors to impede the corrosion, and the Fermilab people are now operating their device successfully.

(8) Multiagency Radiochemistry Laboratory Analytical Procedures (MARLAP) Manual (L.L. Smith)

The Multiagency Radiochemistry Laboratory Analytical Procedures (MARLAP) Manual is a multiagency [EPA, DOE, the Department of Defense (DOD), and the Nuclear Regulatory Commission (NRC)] document that currently is being completed to provide guidance to laboratory personnel and project managers in all relevant areas of radioanalytical laboratory work. The MARLAP manual discusses the theory and background of various analytical 
techniques, as applied to samples containing radiological analytes. It is designed to be of use to developers of analytical standard operating procedures, so they can understand various options and choose the best analytical approach for a given situation.

Because of our radiological expertise, the ACL was asked to provide technical support to the MARLAP Manual. This technical support included writing significant sections of the manual as well as reviewing the work of other authors. Last year, members of the ACL authored the Sample Dissolution, Separation Techniques, and Evaluation of Radiological Laboratories chapters. This year, the ACL was asked to write the Sample Preparation chapter. Following interagency review, this manual should be published in FY01.

(9) The Department of Energy's National Analytical Management Program: Projects at Argonne National Laboratory (W. E. Streets)

Over the course of several years, the National Analytical Management Program (NAMP) and its predecessors have developed four centralized information databases designed to allow DOE Complex personnel to share information about DOE's Office of Environmental Management (EM) contacts at the various sites, pertinent methodologies for environmental restoration and waste management, costs of analyses, and performance of contracted laboratories. These databases are the DOE Procedures Database, which was used to produce a World Wide Web (WWW) document, DOE Methods for Evaluating Environmental and Waste Management Samples (DOE Methods Compendium); the National Sample Tracking System (NSTS); the Directory of EM Sampling and Analysis Resources (DEMSAR); and the Integrated Performance Evaluation Program (IPEP). The IPEP database is being developed by ACL and has been at Argonne National Laboratory since its inception. In FY99, NAMP requested that the other three databases be transferred from the Radiological and Environmental Sciences 
Laboratory (RESL) in Idaho to ANL to allow consolidation and streamlining of the gathering of information required for IPEP reports and other projects within the NAMP. Staff from CMT's Computer, Applications, Network, and Security Group (J. M. Copple, J. E. Kulaga, and A. E. Scandora) are assisting the ACL in the development of strategies and systems for the NAMP projects.

After successfully transferring and establishing the DEMSAR and NSTS databases on to ANL servers, we proposed restructuring the elements in these two databases with those in the IPEP Laboratory Identification Database into a common database. After presenting the proposal at the NAMP '99 meeting in June 1999 and receiving sponsor approval, we developed this common database and will use it to demonstrate our products at a meeting of the users of the data in October 1999.

We linked this new database to the IPEP database. The IPEP is designed to provide information on the quality of radiological and nonradiological analytical data being produced by all analytical chemistry laboratories that provide DOE and its contractors with data on environmental restoration and waste management samples. The IPEP collects data from four national performance evaluation (PE) program studies: EPA's Water Supply (WS) and Water Pollution (WP) PE Studies Programs, the DOE Environmental Measurements Laboratory's Quality Assessment Program, and RESL's Mixed Analyte Performance Evaluation Program. In past years IPEP has developed formats for the reports on laboratory performance, and we now continue to accumulate PE program data and to produce reports on laboratory performance on a routine basis. We developed password-secured Internet access to the reports, which can now be generated as needed by various DOE organizations on the IPEP WWW server (http://www.cmt.anl.gov/ipep/ipep.html), after pertinent contract information about which 
analytical laboratories are being used for what analyses by these organizations is entered into the new NAMP common database. The contract information must be collated with the IPEP data collected from the various PE programs to determine whether a laboratory is participating in the appropriate PE programs for the analytical work it is performing in support of EM programs and projects.

As the EPA continues its privatization of the WS and WP Studies Programs through the National Environmental Laboratory Accreditation Program, the IPEP staff has maintained contact with the EPA National Exposure Research Laboratory in Cincinnati to ensure a smooth transition and continued access to the relevant PE information needed by the IPEP.

The files for the DOE Methods for Evaluating Environmental and Waste Management Samples (DOE Methods Compendium) were established on our ANL server, repairs were made to hyperlinks, and sponsor requested amendments were made. The revised document was then renamed The U.S. Department of Energy Methods Compendium and mounted on the IPEP WWW server.

Preparation of Uranium Standard Near Natural ${ }^{236}$ U Concentration

(A. M. Essling, F. Markun, and D. G. Graczyk)

Researchers in ANL's Physics Division (PHY) (I. Ahmad, M. Paul) are using the Argonne Tandem-Linear Accelerator System (ATLAS) to study ${ }^{236} \mathrm{U}$ distribution in nature and in the environment by accelerator mass spectrometry. This isotope of uranium occurs in nature in extremely low abundance, with the ${ }^{236} \mathrm{U}$-to-total- $\mathrm{U}$ atom ratio being approximately $10^{-10}$. To aid their measurements, the ACL was asked to prepare a uranium oxide sample that would contain a known addition of ${ }^{236} \mathrm{U}$ in a matrix of uranium with the natural isotopic composition. The goal was to spike a portion of natural uranium with ${ }^{236} \mathrm{U}$ at an atom ratio of $5 \times 10^{-10}$. The ACL was 
fortunate to have available several grams of uranium dioxide that had been saved since the Manhattan project as an example of isotopically natural uranium. This pre-war $\mathrm{UO}_{2}$ was the perfect substrate for the desired spiked sample. In addition, we obtained isotopically pure ${ }^{236} \mathrm{U}$ that is used as an isotope-dilution spike in low-level uranium measurements by alpha spectrometry. To prepare the spiked sample, we first determined very carefully the ${ }^{236} \mathrm{U}$ concentration in a solution of the isotope and diluted the solution so that a sufficiently small amount of ${ }^{236} \mathrm{U}$ could be reliably measured out. Then, we dissolved $1 \mathrm{~g}$ of the pre-war $\mathrm{UO}_{2}$ in nitric acid and added the appropriate amount of ${ }^{236} U$ to the solution. By evaporating the solution to dryness and igniting the resultant uranyl nitrate to form uranium oxide, we created a uranium oxide material having an abundance of ${ }^{236} \mathrm{U}$ over natural uranium of $(5.17 \pm 0.07) \times 10^{-10}$. A second portion of the pre-war $\mathrm{UO}_{2}$ was carried through an identical process, but without adding spike, to ensure that any contamination of the material would be detected. Unfortunately, problems with the ATLAS operations precluded the low-abundance ${ }^{236} \mathrm{U}$ measurements from being made as scheduled, so the validity of the spiking operations has not been tested. It is anticipated that this product will eventually contribute to an accurate measurement of the natural ${ }^{236} \mathrm{U}$ abundance.

\section{Sister Laboratory Agreement with Costa Rica (L. L. Smith)}

In November 1998, Argonne entered into a sister laboratory agreement with the Atomic Energy Commission of Costa Rica. This program provides assistance in peaceful uses of nuclear energy and science to signatories of the Non-Proliferation Treaty. The five-year agreement opens the way for joint projects, exchanges of scientific and technical information, visits, use of facilities and other technical cooperation, exchanges of samples, materials, instruments and components for testing, training, and assistance in purchasing hard-to-obtain laboratory 
equipment. This program was initially sponsored by the Arms Control and Disarmament Agency, but is currently administered by the U.S. State Department.

As part of this agreement, members of the ACL and the Environmental Research Division visited the Laboratorio de Fisica Nuclear Aplicada Universidad de Costa Rica to teach and to transfer technology developed at ANL (i.e., Empore ${ }^{\mathrm{TM}}$ and Eichrom ${ }^{\mathrm{TM}}$ methodologies) to our Costa Rican colleagues. The techniques presented by the ANL team will allow scientists in Costa Rica to determine the presence of radionuclides in air and aqueous systems. Various methodologies for measuring radium, lead, and the actinides were presented. The ANL-Costa Rica team intend to pursue funding for a joint project to apply these techniques to the monitoring of effluents from active volcanoes.

\section{(12) Separation of Ti-44 from Scandium Metal (D. L. Bowers)}

Physics Division personnel wanted to measure the cross section of the ${ }^{44} \mathrm{Ti}(\alpha, \mathrm{p}){ }^{47} \mathrm{~V}$ reaction, which has significant cosmological implications. A disc of scandium metal was irradiated at the Intense Pulsed Neutron Source to produce ${ }^{44} \mathrm{Ti}\left({ }^{45} \mathrm{Sc}, \mathrm{p}, 2 \mathrm{n}\right)$ and then given to the ACL for chemical separation. It was first dissolved with a mixture of nitric and hydrofluoric acids. Excess HF precipitated out the scandium, and the supernatant liquid containing the ${ }^{44} \mathrm{Ti}$ was then evaporated to dryness. Because this procedure did not remove all of the scandium, an additional separation step was performed. The scandium residue from the first precipitation step

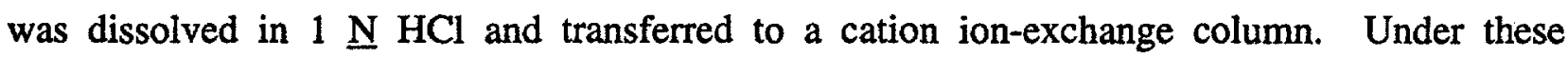
conditions, the ${ }^{44} \mathrm{Ti}$ is adsorbed and the unwanted $\mathrm{Sc}$ is eluted. The ${ }^{44} \mathrm{Ti}$ was stripped from the

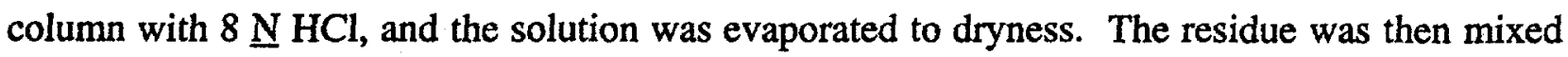
with nat ${ }^{\mathrm{TiO}} \mathrm{O}_{2}$ and heated with a Bunsen burner to convert the ${ }^{44} \mathrm{Ti}$ to ${ }^{44} \mathrm{TiO}_{2}$, which was then placed in a copper holder. It was then transferred to the PHY staff, who inserted it into the 
ATLAS. The source provided an adequate beam of ${ }^{44} \mathrm{Ti}$ ions, and they successfully completed their experiments.

(13) Preparation of Osmium-189 Targets for Photon Excitation Studies (F. Markun)

In collaboration with PHY researchers (D. S. Gemmell and I. Ahmad), the ACL prepared an osmium target for photon excitation studies by electroplating osmium metal onto a copper backing. The resulting metal planchet was then used as a target for photon excitation studies in which the high flux of photons from the Advanced Photon Source (APS) would excite osmium nuclei by a Nuclear Excitation by Electronic Transition (NEET) process. In prior work, the preparation of osmium targets was very successful. Osmium tetraoxide $\left(\mathrm{OsO}_{4}\right)$ was dissolved in a plating solution containing sodium hydroxide, sodium monohydrogen phosphate, sulfamic acid, and potassium hydroxide. The osmium from this solution was then electroplated.

More recently we produced ${ }^{189} \mathrm{Os}$ isotope targets from metallic osmium rather than osmium oxide. Only $100 \mathrm{mg}$ of metallic ${ }^{189} \mathrm{Os}$ powder was available. In order to insure the successful conversion of ${ }^{189}$ Os metal into osmium tetraoxide, a separate experiment was carried out successfully with "natural" metallic osmium. To convert metallic osmium into osmium tetraoxide, the metal must be heated in the presence of oxygen, which produces gaseous osmium tetraoxide. A special apparatus was assembled to efficiently trap all of the gas generated, which was dissolved in a plating solution. The ${ }^{189}$ Os electroplated targets produced were used in APS and generated very useful data.

Based on experimental results with ${ }^{189} \mathrm{Os}$, additional experiments were designed where ${ }^{189}$ Os was electroplated on both sides of a much thinner copper disk $(0.005$ in., or $0.127 \mathrm{~mm}$, thick). In addition, PHY personnel also designed a target holder to accommodate six areas, 
$8 \mathrm{~mm} \times 6 \mathrm{~mm}$, of prepared ${ }^{189}$ Os target material. This new experiment is expected to improve their experimental sensitivity by a factor of 10 to 15 .

The Physics Division supplied $320 \mathrm{mg}$ of ${ }^{189}$ Os metal, which was converted into osmium tetraoxide, as described above. With the newly prepared osmium plating solution, ACL was able to prepare five 0.75 -in.-(19.05-mm-) diameter, 0.005 -in.-(0.127-mm-) thick copper disks plated on both sides with $10 \mathrm{mg} / \mathrm{cm}^{2}$ of ${ }^{189} \mathrm{Os}$. The electroplating was successful after modifying the previously used electroplating apparatus. The newly prepared ${ }^{189}$ Os target arrangement is ready to be placed into the APS photon beam as soon as the flux reaches the desired level.

Radiological Analysis Support for U.S. EPA Region V (F. J. Martino, T. TenKate, F. Markun, L. L. Smith, and D. L. Bowers)

Since 1994, the EPA and ACL have participated in an Interagency Agreement (IAG) intended to provide EPA Region V with special analytical services (SAS) for samples collected in that region. The IAG requires that, to the extent possible, SAS samples be analyzed by methods found in the EPA compendium, Test Methods for Evaluating Solid Waste, Physical/Chemical Methods, SW-846. Alternative methods may be used with prior EPA approval. For the past two years, analytical effort has been principally focused on mixed waste samples, which have been submitted as a part of EPA remediation and site cleanup projects.

A large number of samples were received in 1999 for the determination of ${ }^{226} \mathrm{Ra}$ and ${ }^{228} \mathrm{Ra}$. The samples were submitted as a continuation of three major site remediation programs: Ottawa (Ottawa, IL), Benton Harbor (Benton Harbor, MI), and Lindsay Light (Chicago, IL).

Ottawa was the site of a company that applied luminescent paint containing ${ }^{226} \mathrm{Ra}$ to clock dials. Samples were taken from landfills used to hold waste removed from this site after its demolition, the area around the company building foundation, and the surrounding grounds. Ten 
water and 15 soil samples were submitted to the ACL for the determination of ${ }^{226} \mathrm{Ra}$ and ${ }^{228} \mathrm{Ra}$ by gamma spectroscopy and ${ }^{235 / 238} \mathrm{U}$ and ${ }^{232} \mathrm{Th}$ by alpha spectroscopy. Analytical results were reported in Contract Laboratory Program- (CLP-) type data packages, which contained all analytical results, quality control data, instrument output, and other documentation associated with the samples, including notebook entries, and chain-of-custody forms.

Benton Harbor Warehouse was the site of a privately owned facility used to store hundreds of WWII artifacts, including airplane instrument panel gauges, switches, and compasses coated with luminescent paint containing ${ }^{226} \mathrm{Ra}$. Material stored there was found to be contaminated with radium dust from deteriorating gauges. After a preliminary investigation, the site contractor determined that some of materials could be collected and shredded to form a nearly homogenous sample. This work was completed and reported in the ACL's Progress Report for FY 1998 (ANL 98/2). This year, a subsequent investigation of the grounds surrounding the demolished buildings resulted in 26 water and 67 soil samples being submitted to the ACL for the determination of ${ }^{226 / 228} \mathrm{Ra}$ and ${ }^{226} \mathrm{Ra}$, respectively. Results obtained by gamma spectroscopy were reported in CLP-type data packages, which contained all analytical results, quality control data, instrument output, chain-of-custody records, notebook entries, and other related documentation.

Lindsay Light is the site of what remains of a company that manufactured thorium lantern mantles in the Chicago downtown area. Current plans for construction in that area has the EPA sampling the grounds for ${ }^{226} \mathrm{Ra}$ "hot spots." As part of its remediation plan, the ACL received 25 soil samples for analysis by gamma spectroscopy. All data has been forwarded to the Region $\mathrm{V}$ Office. 
Late in 1999, the EPA expanded its IAG with the ACL to include analytical research as part of an EPA counterterrorism program. The EPA expects to support the FBI, FEMA, and other federal and state agencies for the consequence management phase in response to a suspected terrorist incident. One of these functions will be to provide analysis of suspected chemical agents as needed through the Dilute Facility of the Center for Environmental Restoration Systems. Additional information about this project will be found in the ACL progress report for FY00.

Measurement of Carbon in Lithium Aluminate Ceramics (D. G. Graczyk, F. P. Smith, C. T. Snyder, and A. M. Essling)

The ACL continues to investigate alternative methods for the chemical analysis of lithium aluminate ceramic materials. The goal of this work is to determine whether certain established and qualified but inefficient methods can be replaced with modern alternatives that would be more attractive for production-lot analyses in private sector laboratories. Evaluation of several methods this year culminated in the preparation of documented operating procedures and successful demonstration tests. One demonstrated method is described in this section. Work carried out on other methods is described elsewhere in this report (see Section II.16 through II.19).

One of the new procedures uses an instrumental combustion method to measure total carbon in lithium aluminate and replaces the acid-reaction/carbon dioxide-evolution method currently used to measure carbonate impurity. We found that while measured total carbon concentrations correlated strongly with carbonate content, lithium aluminate specimens also contained carbon in forms other than carbonate. Based on these results, the sponsor reviewed the lithium aluminate specifications and replaced the carbonate limit with a limit on total carbon. 
This change better addressed concerns over incomplete decomposition of carbon-containing precursor or additive constituents, which were the basis for the carbonate limit, and, at the same time, permitted use of the more efficient instrumental method by laboratories that test the ceramic materials. The validation demonstration for the new procedure provided data that verified acceptable precision, bias, and detection limits for the carbon measurements.

(16) Microwave-Accelerated Acid Dissolution of Lithium Aluminate

(A. M. Essling and D. G. Graczyk)

A new procedure developed for dissolving lithium aluminate ceramics replaces the established sealed-tube (Carius tube) method with a method that uses a newly available microwave-heated sample digestion system. The ACL has established conditions for dependable, complete dissolution of lithium aluminate ceramics with the microwave system and has demonstrated an SOP for the process. In this procedure, a 0.3-g sample is placed in the closed-vessel system with $30 \mathrm{~mL}$ of $6 \mathrm{M} \mathrm{HCl}$ and $0.2 \mathrm{~mL}$ of $\mathrm{HF}$ and heated at $240^{\circ} \mathrm{C}$ for 60 minutes. We found the amount of $\mathrm{HF}$ included in the mixture to be important: if too little was used, then some impurity elements did not dissolve; if too much was used, then insoluble aluminum fluoride formed. In addition, we discovered that the type of temperature sensor used for system control affected the ability to process multiple samples. Only a fiber-optic sensor gave even heating between the control vessel and other vessels present in the microwave cavity at the same time.

Because the required conditions lie at the edge of the operating limits for the microwave system, there was almost no base of experience on the long-term performance that might be expected in applying the ACL process to a production setting. During the past year, we processed a number of sample groups to accumulate such experience and to identify problems 
that might arise during repetitive use of the apparatus. One such problem identified was frequent venting of individual closed digestion vessels during the heating cycle. Through discussions with the system manufacturer and limited experimentation, the problem was traced to defects developing in the vessel caps. The operating procedure was modified to include inspection criteria that help recognize such defects before they cause venting and the associated wasted effort of losing and having to reprepare a sample.

The microwave-accelerated acid-dissolution procedure is now fully developed. It is as effective as the Carius tube method in dissolving lithium aluminate, is fairly convenient to apply, and should be easily transferable to commercial sector laboratories for production-lot analysis. The solution obtained is suitable for use in lithium isotopic analysis, lithium and aluminum assay, and determination of cation impurities by spectroscopic methods.

High-Precision Assay of Lithium and Aluminum by ICP/AES (D. G. Graczyk, D. R. Huff, S. J. Lopykinski, and A. M. Essling)

Another new method for the chemical analysis of lithium aluminate (see preceding sections) that the ACL has started to implement is a novel methodology developed at the National Institute of Science and Technology (NIST). It allows exceptionally precise measurements using ICP/AES by applying a drift-correction algorithm to compensate for longterm noise in a series of internal-standard-corrected measurements. This approach has been used by NIST to measure the lithium and aluminum content of lithium aluminate ceramics and offers considerable advantages compared to the classical methods currently used (isotope dilution for determining lithium and gravimetric analysis for aluminum). The ACL is seeking to demonstrate that the NIST approach can be established in other laboratories where reasonable skills exist. In 
addition, we will formulate the NIST approach into an SOP that can be qualified and transferred to private sector laboratories for lithium and aluminum assay of production-lot ceramics.

Early work in the ACL showed that the method provided excellent precision (relative standard deviation $0.1 \%$ ) with our grating-polychromator instrument when standard solutions were analyzed. Later work with standards that contained lithium and aluminum in differing proportions and measurements with lithium aluminate materials of known composition, however, indicated that the data could be biased by matrix effects. These effects appear to have been overcome for aluminum by selecting appropriate ICP/AES operating conditions. With lithium, a more daunting problem arose from isotopic composition differences between samples and standards. Because the grating polychromator achieves partial resolution of the isotopic emission wavelengths from ${ }^{6} \mathrm{Li}$ and ${ }^{7} \mathrm{Li}$ and the detector configuration collects light from only a small window on the emission peak, the grating system does not allow correction for isotopic differences. This effect may ultimately obviate the use of a grating system for lithium assay with the NIST approach. Using solutions prepared from the microwave-accelerated acid-dissolution procedure described earlier in this report, aluminum assays were achieved with a precision of a few tenths of a percent RSD and a relative bias smaller than $0.3 \%$. These results indicate that the sample preparation and handling methodology established in the ACL is capable of meeting the goals of high precision and small bias for assay of the lithium aluminate major constituents, and that the currently available procedures and equipment will provide satisfactory aluminum assays. To apply the methodology to the lithium assay, instrumentation with array detection, comparable to that used by NIST in their measurements, appears to be required. Because the ICP/AES methodology shows such decided advantages over classical methods, we hope to continue work on the lithium assay in FY00. 
(18) Effect of Aluminum on Lithium Isotopic Analysis by Thermal Ionization Mass

Spectrometry (F. P. Smith, A. M. Essling, and D. G. Graczyk)

The procedure currently in use for lithium isotopic analysis by thermal ionization mass spectrometry (TIMS) in the ACL permits direct loading of dissolved lithium aluminate sample on the TIMS filament assembly. A question arose in discussions with the NIST about whether the presence of aluminum in such samples might introduce a correctable bias into the TIMS isotope ratio measurements when the system is calibrated with lithium isotopic standards that do not contain the aluminum. In a 1997 interlaboratory comparison that included both NIST and the ACL, ACL's results for a lithium aluminate sample differed from NIST's by $+0.37 \%$. In analyzing this sample, NIST separated the aluminum from the lithium before analysis but ACL did not. To answer the question of whether the bias is related to the presence of aluminum, $A C L$ analysts analyzed a set of lithium isotopic standards after adding a stoichiometric (1:1) amount of aluminum to simulate dissolved $\mathrm{LiAlO}_{2}$. Results from analyzing these samples showed that the aluminum increased the measured ${ }^{6} \mathrm{Li} /{ }^{7} \mathrm{Li}$ isotope ratio by $0.42 \pm 0.23 \%$, relative. After adjustments for this effect, the ACL and NIST values for the intercomparison sample come closer together and agree within $0.05 \%$, relative to the NIST value. The ACL procedure has been modified to add aluminum to the lithium isotopic standards when the TIMS instrument is calibrated for analysis of lithium aluminate. This modification will improve the accuracy of the analysis while maintaining the simplicity of operations associated with direct loading of the sample solutions. 
(19) Method for Determining Halide Impurities in Refractory Materials

(A. M. Essling, F. P. Smith, and D. G. Graczyk)

Measuring small amounts of halides contained in refractory materials is difficult because methods generally used for decomposing the refractory materials can volatilize the sought-for elements or introduce reagents (e.g., hydrochloric or hydrofluoric acid) that interfere with their determination. One approach that has been considered in the ACL for some time is to decompose siliceous or aluminosilicate refractories by fusion with potassium hydroxide, treat the fusate with water, and measure the halides in the resulting basic solution with ion chromatography. Although sometimes successful, this approach often failed when the aluminum content of the refractory was so high that fluoride was complexed or when the halide content was low. Recently, we tried a modification of the method that appears to overcome these problems for analyzing lithium aluminate. In this method, a $0.5-\mathrm{g}$ sample is fused with $4 \mathrm{~g}$ of $\mathrm{KOH}$ in a zirconium crucible. The fusate is carefully neutralized and then dissolved with dilute sulfuric acid, which completely decomposes the sample. Then, more sulfuric acid is added and the halides are steam distilled from the mixture. The distillate is analyzed by ion chromatography. Preliminary tests of the method have shown that when the distillation is carried to incipient fumes of sulfuric acid (pot temperature of $205^{\circ} \mathrm{C}$ ), near-quantitative recovery of fluoride and chloride is achieved at levels equivalent to $0.03 \mathrm{wt} \%$ in the solid sample. Bromide recoveries were on the order of $80 \%$ at the same concentration levels. Iodide is lost during the distillation when aluminum is present, presumably through oxidation to iodine that is not retained in the distillate. If additional testing upholds these initial observations, this new approach will be applied to lithium aluminate ceramics. It promises to be useful for analyzing glasses, zeolites, wasteform samples, and other materials as well. 
(20) Assembled Chemical Weapons Assessment Program (C. T. Snyder, W. E. Egan, and A. S. Boparai)

The U.S. Army's Chemical Agent Munitions Disposal System (CAMDS), which is part of the Assembled Chemical Weapon Assessment (ACWA) Program, is evaluating alternative technologies to incineration for decommissioning and disposal of munitions containing chemical warfare agents. The Deseret Chemical Depot (DCD) near Tooele, Utah, is a major storage site for several of the chemical warfare agents. For agent GB (Sarin, which is isopropyl methylphosphonofluoridate), the technologies under consideration all begin with chemical neutralization using a strong caustic solution of $10 \%$ sodium hydroxide. Sodium hydroxide solution rapidly hydrolyses GB into various degradation products. The resulting solution of caustic and degraded GB is called "hydrolysate." The Army is producing a large amount of hydrolysate to be used in tests of various alternative technologies, which will be carried out by various contractors. In order for the Army to provide hydrolysate samples to contractors, the GB concentration in the hydrolysate must be no higher than the Army's drinking water standard for GB of $20 \mu \mathrm{g} / \mathrm{L}$. In collaboration with personnel of the Chemistry Division (N. Tomczyk) and Energy Systems Division (J. F. Schneider, H. J. O'Neill, K. L. Brubaker, and L. L. Reed), the ACL is providing on-site technical assistance in the analysis of hydrolysate. This assistance includes site-specific and chemical surety training for several ANL chemists; two analysts worked every week in the Dilute Facility Laboratory at the DCD site during the analytical method setup and method validation period, as well as during the production of the hydrosylates.

The work has involved both the adaptation of the Army's GC/MS method for determining GB in hydrosylate at the 20-ppb level and the preparation of the analytical laboratory in Utah. The sample preparation method has been streamlined to minimize exposure 
of the analysts to hydrosylates and to maximize recovery of unreacted GB. Method detection limits have also been determined using GB hydrosylate provided by the Army for the liquid and solid components of the hydrosylate. After the method was validated, many field samples were analyzed for the presence of GB.

(21) Characterization Of Unidentified Waste Materials (D. G. Graczyk, A. M. Essling, D. R. Huff, E. A. Huff, S. J. Lopykinski, F. P. Smith, L. B. TenKate, D. L. Bowers, P. L. Johnson, F. Markun, L. L. Smith, B. S. Tani, T. TenKate, A. S. Boparai, L. L. Chromizky, and M. J. Kalensky)

Many ANL facilities have unidentified waste materials that have unknown origins or inadequate documentation or that remain from programs that are no longer active. These wastes must be characterized and documented so that they can be disposed of properly. In support of this effort, the ACL performs chemical and radiological analyses to provide the composition and hazards-classification data needed by the treatment/storage/disposal facilities that ultimately process the wastes. Working closely with the Plant Facilities and Services - Waste Management Operations (PFS-WMO) staff, the ACL helps assure that the informational and procedural requirements of the appropriate facility are satisfied.

Many different types of wastes were characterized by the ACL in FY 1999. Beakers, flasks, and bottles containing unlabeled radioactive solids and liquids from two ANL-E radioactive material handling facilities were characterized, as were unidentified solids, sludges, aqueous and organic liquids, and oils from several ANL-E divisions. Commercial solvents, cleaners, and other compounds with no list of ingredients and no MSDS information, also from several divisions, were characterized. 
When the materials appeared to be pure chemical compounds or simple mixtures, the ACL identified the material and then supplied the submitter with an MSDS listing the pertinent hazard information. Direct identification of solids was provided by X-ray diffraction (XRD) and/or scanning electron microscopy (SEM). Direct identification of liquids was provided by GC/MS or Fourier transform infrared spectroscopy (FTIR). Those wastes that could not be identified or that proved to be complex mixtures were evaluated for the RCRA characteristics of ignitability, corrosivity, toxicity, and reactivity. These evaluations included the following: $\mathrm{pH}$, water miscibility, and flash point determinations; mercury analysis by Cold Vapor Atomic Absorption (CVAA); and $\mathrm{As}, \mathrm{Ba}, \mathrm{Cd}, \mathrm{Cr}, \mathrm{Pb}, \mathrm{Se}$, and $\mathrm{Ag}$ determinations by ICP/AES. The ACL used GC/MS to identify RCRA target organic components and ion chromatography (IC) to identify any acids present. In some cases the amount of water in a waste had to be determined by a Karl-Fischer titration. Wastes from radiologically controlled areas or wastes suspected of containing radioactivity were analyzed by gamma spectrometry, gas proportional counting, liquid scintillation counting, and/or alpha pulse height analysis.

In virtually every case, the characterization of an unidentified waste is a complex process. It involves constant re-evaluation of the analytical data each time a new component of the waste is identified, so that all the necessary analyses are performed and no components of the waste are left unidentified. Unfortunately, this process makes the characterization of unidentified wastes both costly and time-consuming, which highlights the need for all ANL-E operations to keep timely and complete records of stored materials and to promptly dispose of unneeded materials. 
(22) Quality Assurance Laboratory Support to the U.S. Army Corps of Engineers

(D. W. Green, F. J. Martino, D. L. Bowers, A. S. Boparai, D. G. Graczyk, L. L. Smith, F. Markun, T. TenKate, A. M. Essling, E. A. Huff, D. R. Huff, L. B. TenKate, L. L.

Chromizky, Y. Tsai, and F. P. Smith)

The U.S. Army Corps of Engineers (USACE) in October 1997 assumed responsibility for the Formerly Utilized Sites Remedial Action Program (FUSRAP), which had been the responsibility of the DOE since 1974 . The objectives of this program are to study and remediate sites having radioactive materials from DOE and its predecessors' operations, dating back in some cases to the Manhattan Project.

The Buffalo District of the USACE is responsible for several FUSRAP sites within their jurisdiction. The ACL serves the Buffalo District as a quality assurance laboratory for the analysis of ambient matrix samples (e.g., soil, sediment, ground or surface water) from various remediation sites.

The ACL received 43 samples in FY 1999 from the Luckey, Ohio, site and an additional 18 samples from the Ashland 2 site in Tonawanda, NY. The Luckey site was a magnesium and beryllium processing facility that received radiologically contaminated scrap metal from the Atomic Energy Commission. From 1944 to 1946, during the operation of the Linde Air Products uranium ore processing facility, approximately 8,000 tons of low-grade uranium ore tailings were stored at an area now known as Ashland 1. Between 1974 and 1982, the Ashland Oil Company excavated and moved soil containing low-level radioactive residues from the work of the Manhattan Engineering District from the Ashland 1 Site to an area at Ashland 2. Both the Luckey and Ashland 2 sites are the object of remediation efforts requiring analytical data for making decisions. The role of the ACL is to analyze selected samples to ensure that the production analytical laboratories are providing data that meet the quality requirements of the Buffalo District and the FUSRAP program. 
All organic and inorganic analytes were determined using existing procedures and methods described in the U.S. EPA laboratory manual "Test Methods for Evaluating Solid Waste, Physical/Chemical Methods" (SW-846) in accordance with instructions from the USACE. Radiological measurements were carried out according to U.S. EPA methods and established ANL methods and procedures.

In addition, the ACL received samples through the Baltimore District of the USACE from the Colonie, New York site, in FY 1998; those analyses were completed in early FY 1999. Our data for this site helped the Baltimore District ensure the quality of the data received from the production analytical laboratories.

\section{Data Validation for the U.S. Army Corps of Engineers (L.L. Smith)}

The ACL was requested to validate data from a commercial laboratory that had provided data to the Buffalo District of the U.S. Army Corps of Engineers (USACE) for the remediation program at the Ashland 2 site in Tonawanda, New York. Radiological parameters for isotopic thorium, uranium, and radium were assessed, based upon the criteria required by the Hanford site and specified in "Data Validation Procedures for Radiochemical Analyses" (WHC-SD-EN-SPP001, Rev. 1). This review included an assessment of the performance of the analytical procedures, the counting instrumentation, and the quality assurance samples. The information obtained through this data validation determined the usability of the data in supporting the objectives of the USACE remediation project. 
The Energy Technology Division (G. Fenske, M. Alzoubi, and associates), in cooperation with Tranergy Inc. and Texaco, is testing several proprietary lubricants developed by Texaco to reduce friction between rail tracks and locomotive wheels. The reduction in friction should lead to lower energy consumption by locomotive engines and less wear on the rail hardware. When the engines are in front of the train, the lubricant is applied on the rail tracks behind the engines to allow normal traction between the tracks and the wheels of the engine while friction between the tracks and the rail cars is minimized. The automated system that applies the lubricant calculates the amount of lubricant needed based on the weight of the rail cars and the length of the train. The lubricant is expected to significantly lose its lubrication power as a train passes over the treated tracks and before the next train uses the tracks.

One of the tasks of the project is to identify volatile and semivolatile by-products produced during use of the lubricants. A laboratory-scale device has been constructed by Tranergy, that allows accurate measurement of friction between a simulated track and wheel system. This device was used to apply lubricant and collect residue from the tracks after defined periods of use. The ACL analyzed samples of a lubricant before and after use. The ACL utilized GC/MS to identify major components of the proprietary lubricant. In preliminary work, only minor semivolatile by-products were detected in the lubricant after its use in the test apparatus. Identification of these compounds is in progress. The Tranergy device was modified to collect volatile organic compounds (VOCs) on Tenax traps produced from the use of the lubricant on the simulated track. Analyses of samples for VOCs is under way. 


\section{QUALITY ASSURANCE}

Quality Assurance (F. J. Martino)

Assessments and audits continue to play an important role in helping to ensure client satisfaction. Each assessment and audit serves as an aid in evaluating (1) the degree to which ACL performance corresponds to stated performance requirements, (2) the adequacy of processes established to achieve quality, and (3) the performance of ACL scientific staff in meeting the requirements of the ACL QA Plan and program-related plans and statements of work. It also verifies the existence of documents and procedures. One assessment and one audit of the ACL were performed in 1999 to verify ACL analytical capabilities in support of programs for which the ACL provides analytical services. In April, the CMT Nuclear Waste Management Section assessed the ACL as a provider of analytical services. No corrective action issues were identified during this assessment. In July, Pacific Northwest National Laboratory audited ACL performance in meeting program requirements governing the development of analytical methods for the dissolution and analysis of $\mathrm{LiAlO}_{2}$ as a part of the Tritium Target Qualification Program. All corrective actions identified during this audit are being addressed, with resolution expected during November 1999. In both the assessment and audit, the ACL demonstrated control over its processes.

Performance evaluation (PE) programs provide intercomparison studies for participating analytical laboratories and provide an independent evaluation of performance. Participation in such programs are often a requirement for laboratories providing analytical results in support of EPA and DOE programs. In some cases, the programs are also a requirement for laboratories seeking state certification or validation by a federal agency. The only programs currently coordinated and monitored by a government agency for the purpose of laboratory performance 
verification are those which the DOE provides. Programs that provided blind (i.e., analyte values known only to the monitoring agency) PE samples to the ACL in 1999 are listed below. Each of these PE programs has served to support of the quality of ACL analytical results.

- DOE Environmental Measurements Laboratory Quality Assessment Program (EML QAP): Two PE samples (QAP 49 and QAP 50) were received and analyzed to identify and quantify a variety of radionuclides, using gross $\alpha / \beta, \gamma$ spectroscopy, and $\alpha$ spectroscopy techniques. Soil, water, vegetation, and air filters were included in this study. An evaluation of our results indicates that the ACL correctly identified all radionuclides present.

- DOE Mixed Analyte Performance Evaluation Program (MAPEP): All laboratories reporting mixed-waste analytical measurements for EM-sponsored work are required to participate in this DOE semiannual program. The MAPEP water and soil PE samples are prepared as a mixture of inorganic, semivolatile organic, and radiological analytes, to create a blind mixedwaste sample. Analysis of these PE samples provides a way to evaluate and ensure the quality and defensibility of analytical measurements generated for client mixed-waste samples. In 1999, the ACL participated in two such sample studies, MAPEP 98-W6 and 99S6. The ACL correctly identified all inorganic, semivolatile organic, and radiological analytes in MAPEP 98-W6. High levels of chromium, selenium, and vanadium determined in this water sample were attributed to an improved sample digestion method (microwave), which led to higher levels of recovery. Data for MAPEP 99-S6 were prepared and reported in October. The ACL also correctly identified all inorganic, semivolatile organic, and radiological analytes in MAPEP 99-56. A slightly high level reported for cadmium is being investigated. 
- Army Corps of Engineers (USACE): As a part of their responsibility to coordinate the remediation of FUSRAP sites (see additional information in Section II.23 ), the USACE asked the ACL to become validated in order that it might serve as their quality control analytical laboratory for the purpose of analyzing FUSRAP site samples and establishing baseline sample data. One of the validation requirements was that the ACL successfully analyze inorganic and organic PE samples. This validation requirements was satisfied with the successful analysis of both samples. 


\section{PROFESSIONAL ACTIVITIES}

\section{A. Publications and Reports}

Effect of Spectral Resolution on Pattern Recognition Analysis Using Passive Fourier Transform Infrared Sensor Data

A. S. Bangalore, J. C. Demirgian, and A. S. Boparai

Applied Spectroscopy, 53(11) 1999

Analytical Chemistry Laboratory Progress Report for FY 1998

D. W. Green, A. S. Boparai, D. L. Bowers. D. G. Graczyk, P. C. Lindahl, with contributions from ACL Staff

Argonne National Laboratory Report ANL/ACL-98/2 (1998)

Management Style - What Is It?

D. W. Green

Managing the Modern Laboratory, 3(3), 45A-46A (1998)

Chemistry and Management Education and Training

D. W. Green

Managing the Modern Laboratory, 3(2), 29A-31A (1998)

Forum on When is Quality Assurance Cost Effective

D. W. Green

Managing the Modern Laboratory, 3(4), 68A-75A (1999)

What is Important

D. W. Green

Managing the Modern Laboratory, 3(4), 59A-60A (1999)

Fads, Truth, Wisdom, and Experiments

D. W. Green

Managing the Modern Laboratory, 4(1), 2A-3A (1999)

Team Celebration

D. W. Green

Managing the Modern Laboratory, 4(2), 19A (1999)

Fluid-Based System for Radon Mitigation

K. C. Gross and F. Markun

Published in the Proceedings of the 1999 International Radon Symposium, sponsored by the American Association of Radon Scientists and Technologists, Las Vegas, NV, November 9-12, 1999 
FTIR and Hyphenated FTIR Techniques for the Analysis of Foods

G. T. Reedy and Magdi M. Mossoba

Spectral Methods in Food Analysis-Instrumentation and Applications, 7 325-396 (1998)

Radiochemical Analysis Using Empore ${ }^{\mathrm{TM}}$ Rad Disks

L. L. Smith and K. A. Orlandini

Proc. of the GLOBAL '99 International Conference on Future Nuclear

Systems, Jackson Hole, WY, August 29-September 3, 1999

\section{B. Oral Presentations}

Analysis of High Burnup Nuclear Fuel by HPLC-ICPMS

S. F. Wolf and D. L. Bowers

ASTM Committee C-26 on Nuclear Fuel Cycles, Memphis, TN, January 24-28, 1999

Material Accountancy Measurement Techniques in Dry-Powdered Processing of Nuclear Spent Fuels

S. F. Wolf, D. L. Bowers, P. J. Persiani, Jong-Sook Hong, and Ho-Dong Kim, ESARDA, Seville, Spain, May 4-6, 1999

Demonstration of Packaging of Fernald Silo 1 Waste in Chemically Bonded Phosphate Ceramic
A. S. Wagh, D. Singh, S. Y. Jeong, D. G. Graczyk, and L. B. TenKate
Waste Management Symposium '99, Tucson, AZ, February 28-March 4, 1999

Common Interests of the DOE Analytical Managers Group (DAM) and the DOE Metrology Committee

D. W. Green

$$
\text { DOE Metrology Meeting, Las Vegas, NV, March 24, } 1999
$$

Becoming a Better Analytical Lab Manager

D. W. Green

Symposium on "Managing the Modern Analytical Laboratory, $50^{\text {th }}$

Pittsburgh Conference and Exposition on Analytical Chemistry and

Applied Spectroscopy, Orlando, FL, March 8, 1999

Are Analytical Chemists Metrologists?

D. W. Green

$17^{\text {th }}$ Annual Meeting of the DOE Analytical Managers Group, Idaho Falls,

ID, August 17-19, 1999 
Better Radiological Measurements through Better Sample Preparation

D. W. Green and L. L. Smith

Presented at the $218^{\text {th }}$ National Meeting of the American Chemical

Society, Division of Analytical Chemistry Awards Symposium, New

Orleans, LA, August 22-26, 1999

Implementation Details for NAMP Information Systems

A. E. Scandora, W. E. Streets, J. S. Morton, L. Ekman, and S. Woolf

NAMP '99: Analytical Solutions for Successful Environmental Cleanup,

Gaithersburg, MD, June 15-17, 1999

ANL's Role in the Destruction of Chemical Warfare Agents

J.F. Schneider and A. S. Boparai

CMT Technical Seminar, June 25, 1999

Empore ${ }^{\mathrm{TM}}$ Rad Disks: Waste Minimization through an Innovative Sample Preparation Technique

L. L. Smith

$13^{\text {th }}$ International Forum on Process Analytical Chemistry, IFPAC '99,

San Antonio, TX, January 24-27, 1999

Radiochemical Analysis Using Empore ${ }^{\mathrm{TM}}$ Rad Disks

L. L. Smith and K. A. Orlandini

GLOBAL ' 99 International Conference on Future Nuclear Systems, Jackson Hole, WY, August 29-September 3, 1999

Empore $^{\mathrm{TM}}$ Solid-Phase Extraction Disks

L. L. Smith

CMT Technical Seminar Series, November 20, 1998

Enhanced Use of Performance Evaluation Program Data in Support of the Department of Energy's Environmental Management Activities

W. E. Streets and P.C. Lindahl

Fifth Great Lakes Conference on Applied Statistics, Kalamazoo, MI, Oct. 21-23, 1998

DOE's Integrated Performance Evaluation Program (IPEP) - A Resource for Promoting Excellence in EM Sampling and Analysis Operations Throughout the DOE Complex

W. E. Streets and P. C. Lindahl,

Tenth National Technical Information Exchange Workshop, Willowbrook, IL, Oct. 27-29, 1998

Development and Implementation of Information Systems for DOE's National Analytical Management Program (NAMP)

W. E. Streets

Waste Management Symposium '99, Tucson, AZ, March 4, 1999 
Development and Implementation of Information Systems for DOE's National Analytical Management Program (NAMP)

W. E. Streets, A. E. Scandora, J. S. Morton, L. Ekman, and S. Woolf

NAMP '99: Analytical Solutions for Successful Environmental Cleanup, Gaithersburg, MD, June 15-17, 1999

Status of Implementation of DOE-EM's NAMP Informational Databases

W. E. Streets

NAMP '99: Analytical Solutions for Successful Environmental Cleanup,

Gaithersburg, MD, June 15-17, 1999

C. Awards and Patents

Edmund A. Huff

The Kenneth J. Jensen Award for Excellence, presented by the Analytical Chemistry Laboratory, Chemical Technology Division, Argonne National Laboratory, November 1998

Francis Markun

U.S. Patent No. 5,952,655; DOE Case No. S-86 893

Entitled: ULTRA-HIGH SENSITIVITY DETECTION RADIATION APPARATUS

AND METHOD

Inventors: Kenneth C. Gross, John D. Valentine, Francis Markun, Mary Zawadski and Charles Dickerman

Issued: September 14, 1999

Lesa L. Smith

Empore ${ }^{\text {TM }}$ Rad Disks

Received recognition as one of the "Top 40 R\&D 100 Winners" of the past 40 years. This award was given to the collaborative research and development effort between

Argonne, the 3M Company, and IBC Advanced Technologies, Inc., 1999

D. Meetings Attended

D. L. Bowers

ASTM Committee-26, Seattle, WA, June 27 - July 1, 1999

$\underline{\text { K. Brubaker }}$

Pittcon '99, Orlando, FL, March 8-12, 1999

D. W. Green

NAMP '99 Workshop, Gaithersburg, MD, June 15-17, 1999

F. P. Smith

NOBCChE Annual Conference, San Diego, CA, April 5-10, 1999 


\section{W. E. Streets}

Interagency Methods and Data Comparability Board Meeting, Denver, CO, August 30 - September 1, 1999

W. E. Streets

Waste Testing and Quality Assurance Symposium, Arlington, VA, July 19-21, 1999

W. E. Streets

Interagency Methods and Data Compatibility Board Meeting, Cincinnati, $\mathrm{OH}$, May 11-13, 1999

\section{W.E. Streets}

Synchrotron Environmental Science Workshop (SES-1), Argonne, IL, April 19-21, 1999

\section{W. E. Streets}

$44^{\text {th }}$ Annual Conference on Bioassay, Analytical and Environmental Radiochemistry, Albuquerque, NM, November 15-20, 1998

\section{E. Professional Organizations and Activities}

Amrit S. Boparai

American Chemical Society

Sigma Xi

Delbert L. Bowers

American Chemical Society

American Society for Testing and Materials

Donald G. Graczyk

American Chemical Society

Sigma Xi

American Society for Mass Spectrometry

\section{David W. Green}

American Chemical Society, Division of Analytical Chemistry

Analytical Laboratory Managers Association, Board of Directors

DOE Analytical Managers Group, Board of Directors

Editor, Managing the Modern Laboratory

Chemical Measurement Task Group, Council on Chemical Research (member)

Sigma Xi

\section{Edmund A. Huff}

American Chemical Society

Society for Applied Spectroscopy

Sigma Xi 
Paul L. Johnson

American Crystallographic Association

Association for Computing Machinery

Sigma Xi

Francis Markun

Health Physics Society, Midwest Chapter

Gerald T. Reedy

American Chemical Society

Society for Applied Spectroscopy

Laurids E. Ross

American Chemical Society

Sigma Xi

American Association for the Advancement of Science

Carmen S. Sabau

American Chemical Society, Chicago Section

Division of Nuclear Chemistry and Technology

American Nuclear Society

Fuel Cycle and Waste Management Division, Chicago Section

Environmental Sciences Division

American-Romanian Academy of Arts and Sciences

Association of Women in Science, Chicago Chapter

Humboldt Association of America

International Society for Intercommunication of New Ideas

New York Academy of Sciences

Sigma Xi

Florence P. Smith

National Organization of Black Chemists and Chemical Engineers

Christine T. Snyder

American Chemical Society

Charles M. Stevens

American Geophysics Union

American Association for the Advancement of Science

Tony TenKate

American Association of Physics Teachers

Sigma Xi 
Lynn B. TenKate

Society for Applied Spectroscopy, Chicago Section

Sigma Xi

F. Professional Training

Amrit S. Boparai

Program Development, October 19-21, 1998, Argonne, IL

David W. Green

Program Development, October 19-21, 1998, Argonne, IL

William J. Egan

Program Development, October 19-21, 1998, Argonne, IL

Florence P. Smith

TC-136 O/N Determinator Training Class, November 18-20, 1998, St. Joseph, MI

Christine T. Snyder

TC-136 O/N Determinator Training Class, November 18-20, 1998, St. Joseph, MI

W. Elane Streets

Microsoft Word Front Page Editor course, February 8-9, 1999, Argonne, IL

Alice M. Birmingham

Management Skills for Executive Secretaries and Administrative Assistants, February 16-17, 1999, Oakbrook Terrace, II

G. ACL Seminars

Empore $^{\top M}$ Solid-Phase Extraction Disks

L. L. Smith

CMT Technical Seminar Series, November 20, 1998

ANL's Role in the Destruction of Chemical Warfare Agents

J.F. Schneider and A. S. Boparai

CMT Technical Seminar Series, June 25, 1999 
Distribution for ANL/ACL-99/2

Internal:

J. P. Ackerman

R. Agarwal

I. Ahmad

I. Ambats

D. V. Applegate

J. G. Asbury

M. D. Atella

A. J. Bakel

L. Baker

U. Balachandran

R. W. Bane

S. G. Barisas

J. E. Battles

W. Berg

P. R. Betten

M. H. Bhattacharyya

S. K. Bhattacharyya

I. D. Bloom

L. E. Boing

A. S. Boparai

R. Bouie

D. L. Bowers

B. S. Brown

E. A. Brown

K. L. Brubaker

E. C. Buck

J. C. Burton

D. E. Busch

Z. Cai

K. P. Carney

Y. I. Chang

M. J. Chen

D. Clayton

A. Cohen

J. T. Collins

R. E. Combs

D. Cummings

J. C. Cunnane

E. Daniels

T. M. Davis

L. W. Deitrich

J. C. Demirgian
C. B. Dennis

M. H. Derbidge

D. R. Diercks

M. L. Dietz

J. D. Ditmars

E. H. Dolecek

S. Dorris

R. Dortwegt

H. Drucker

F. J. Dudek

D. Duncan

B. D. Dunlap

A. J. Dvorak

C. Dwight

W. L. Ebert

D. E. Edgar

P. D. Eichamer

R. E. Einziger

J. W. Emery

A. Erdemir

A. M. Essling

J. K. Fink

F. Y. Fradin

J. R. Frank

S. M. Frank

B. R. T. Frost

J. Gasper

E. C. Gay

D. S. Gemmel

J. M. Gibson

C. Giometti

N. W. Golchert

M. M. Goldberg

K. C. Goretta

D. G. Graczyk

C. Grandy

D. W. Green (50)

J. P. Greene

G. E. Griffin

K. C. Gross

D. M. Gruen

G. R. Gunderson
Y. Halpern

W. H. Hannum

J. E. Harmon

H. M. Hartmann

B. Harvey

H. J. Haupt

R. R. Heinrich

J. E. Helt

W. F. Henning

J. Hensley

J. Herman

D. J. Hill

A. G. Hins

M. J. Holzemer

M. Houser

J. Hryn

H.-S. Huang

E. Huberman

D. R. Huff

E. A. Huff

A. B. Hull

L. Iton

M. J. Janik

D. J. Jankowski

J, D. Jastrow

B. J. Jody

C. E. Johnson

D. O. Johnson

P. L. Johnson

M. J. Kalensky

E. J. Karell

D. Karvelas

T. F. Kassner

T. D. Kaun

T. Kimmell

A. M. Kini

R. G. Kolzow

A. R. Krauss

J. Krazinski

J. R. Krsul

T. C. Kuhfuss

R. Kumar 
B. Lai

J. J. Laidler

T. A. Lang

R. A. Leonard

D. Lewis

M. A. Lewis

J. J. R. Liaw

R. A. Lindley

M. J. Lineberry

C. D. Livengood

S. J. Lopykinski

P. Lynch

R. F. Malecha

F. Markun

B. L. Markwenas

V. A. Maroni

F. J. Martino

B. A. Marzec

S. M. McDeavitt

H. F. McFarlane

R. J. McMahon

C. A. Melendres

V. A. Mendez

W. C. Metz

M. Michlik

J. F. Miller

S. F. Miller

W. E. Miller

D. E. Moncton

L. J. Morrissey

H. S. Morss

L. R. Morss

B. T. Murdoch

E. A. Myatt

H. W. Myron

Z. Nagy

C. Negri

R. E. Nietert

J. W. O'Kelley

H. J. O'Neill

T. L. Patton

D. R. Pedersen

J. P. Peerenboom

M. J. Pellin

R. Peters
D. P. Peterson

J. K. Pfeifer

K. C. Picel

B. F. Picologlou

B. G. Pierce

R. E. Piorkowski

W. F. Podolski

R. B. Poeppel

A. J. Policastro

J. B. Rajan

A. C. Raptis

D. T. Reed

L. L. Reed

C. A. Reilly

M. K. Richmann

S. J. Riley

M. J. Robinet

R. Rosenberg

D. Rosenmann

L. E. Ross

A. B. Rothman

B. Ruscic

C. S. Sabau

W. W. Schertz

R. A. Schlenker

M. W. Schlueter

J. F. Schneider

T. L. Scott

J. Sedlet

W. J. Shack

T. Shearer-Bray

G. K. Shenoy

K. W. Shepard

J. G. Sleeth

D. L. Smith

D. L. Smith

F. P. Smith

L. L. Smith

R. K. Smither

J. L. Snelgrove

C. T. Snyder

V. C. Stamoudis

M. J. Steindler

C. M. Stevens

F. J. Stevens
S. B. Strasser

W. E. Streets

J. Suermann

R. E. Swale

W. M. Swift

T. A. Taiwo

B. S. Tani

J. D. Taylor

L. B. TenKate

T. TenKate

M. C. Thurnauer

D. V. Tolle

D. Tomasko

Z. Tomczuk

M. Torres

A. Travelli

K. Trychta

Y. Tsai

D. D. Tussing

G. F. Vandegrift

$N$. VanWermeskerken

W. R. Vroman

D. C. Wade

W. M. Walsh

L. C. Walters

D. W. Warren

D. W. Werst

M. L. Wesely

C. L. Wilkinson (9)

C. W. Williams

J. L. Willit

A. Wilson

R. E. Winans

R. L. Wittkamp

S. F. Wolf

G. E. Woloschak

R. D. Wolson

J. L. Woodring

A. E. Wright

R. A. Wynveen

C. Yuen

R. E. Zimmerman

S. K. Zussman

TIS Files 
External:

DOE-OSTI (2)

ANL-E Library

ANL-W Library

A. Bindokas, DOE-CH

M. Bollinger, DOE-CH

D. Green, DOE-CH

J. C. Haugen, DOE-CH

M. J. Klimas, DOE-CH

A. L. Taboas, DOE-CH

Chemical Technology Division Review Committee Members:

H. U. Anderson, University of Missouri-Rolla, Rolla, MO

E. R. Beaver, Practical Sustainability, Chesterfield, MO

A. L. Bement, Purdue University, West Lafayette, IN

M. V. Koch, University of Washington, Seattle, WA

R. A. Osteryoung, North Carolina State University, Raleigh, NC

V. P. Roan, University of Florida, Palm Beach Gardens, FL

G. R. St. Pierre, Ohio State University, Columbus, $\mathrm{OH}$

J. H. Aldstadt, University of Wisconsin - Milwaukee, Milwaukee, WI

D. Alexander, Institute of Textile Technology, Spartanburg, SC

A. V. Arakali, West Valley Nuclear Services Co., West Valley, NY

J. Arvizu, CONTECH, Inc., Tijeras, NM

L. M. Bagaasen, Pacific Northwest National Laboratory, Richland, WA

P. Baisden, Lawrence Livermore National Laboratory, Livermore, CA

D. A. Bass, Doctor's Data, Inc., St. Charles, IL

G. Bentley, Los Alamos National Laboratory, Los Alamos, NM

R. Bisping, Fluor Daniel Hanford Inc., Richland, WA

D. W. Bottrell, USDOE, Office of Transportation, Germantown, MD

M. Brown, USDOE, U.S. Department of Energy, Carlsbad, NM

M. H. Carter, USDOE, Office of Transportation, Germantown, MD

L. Casey, USDOE, Office of Defense Programs, Washington, DC

L. L. Chromizky, Darien, IL

J. Connolly, Idaho National Engineering and Environmental Laboratory, Idaho Falls, ID

M. Connolly, Idaho National Engineering and Environmental Laboratory, Idaho Falls, ID

P. T. Cunningham, Los Alamos National Laboratory, Los Alamos, NM

J. Dahlgran, Radiological and Environmental Sciences Laboratory, Idaho Falls, ID

H. J. Dewey, Los Alamos National Laboratory, Los Alamos, NM

B. I. Diamondstone, National Institute of Standards and Technology, Gaithersburg, MD

J. G. Dorsey, Lockheed Martin Energy Systems, Inc., Oak Ridge, TN

A. Edelman, USDOE, Office of Science, Germantown, MD

M. Edelson, Iowa State University, Ames, IA

M. D. Erickson, Environmental Measurements Laboratory, New York, NY

I. M. Fox, Woodridge, IL

B. Freeman, U.S. Environmental Protection Agency, Chicago, IL

T. E. Gills, United States Department of Commerce, Gaithersburg, MD 
P. Greenlaw, Environmental Measurements Laboratory, New York, NY

W. Griest, Oak Ridge National Laboratory, Oak Ridge, TN

G. A. Hansen, U.S. Environmental Protection Agency, Washington, DC

D. C. Hockman, Silliker Laboratories Group, Inc., Homewood, IL

G. Hollenberg, Pacific Northwest National Laboratory, Richland, WA

D. Hunter, Kaiser-Hill Rocky Flats Plant, Golden, CO

R. Hutchinson, National Institute of Standards and Technology, Gaithersburg, MD

J. P. Hysell, Rhone-Poulenc Inc., Cranbury, NJ

L. Jensen, U.S. Environmental Protection Agency, Chicago, IL

J. R. Jordan, Analytical Consumer, Carlisle, MA

M. R. Keenan, Sandia National Laboratories, Albuquerque, NM

C. Klusek, USDOE, Environmental Measurements Laboratory, New York, NY

A. C. Kozminski, U.S. Army Corps of Engineers, Buffalo, NY

T. P. Layloff, Food and Drug Administration, St. Louis, MO

S. C. Lee, Carlsbad Environmental Monitoring and Research, Carlsbad, NM

P. C. Lindahl, Los Alamos National Laboratory, Los Alamos, NM

G. Lopez, Utah Department of Health, Salt Lake City, UT

C. A. Lucchesi, Northwestern University, Evanston, IL

T. Lyttle, Mandeville, LA

J. Mahoney, West Valley Nuclear Services Company, West Valley, NY

M. Mankowski, U.S. Environmental Protection Agency, Chicago, IL

J. J. Marr, Downers Grove, IL.

W. May, National Institute of Standards and Technology, Gaithersburg, MD

M. McCune, USDOE, Washington; DC

W. McKerley, Los Alamos National Laboratory, Los Alamos, NM

R. Mehl, Roy F. Weston, Inc., Vernon Hills, IL

A. Meyer, Fernald Environmental Restoration Management Corporation, Cincinnati, $\mathrm{OH}$

J. Mitchell, U.S. Environmental Protection Agency, Chicago, IL

W. Mitchell, New Brunswick Laboratory, Argonne, IL

C. Moore, U.S. Environmental Protection Agency, Chicago, IL

S. Morton, USDOE, Idaho Falls, ID

R. Murray, USDOE, Federal Energy Technology Center, MGN, Morgantown, WV

L. Newman, Brookhaven National Laboratory, Upton, NY

R. D. Oldham, New Brunswick Laboratory, Argonne, IL

M. Pennington, AlliedSignal Aerospace, Kansas City, MO

J. R. Phillips, Los Alamos National Laboratory, Los Alamos, NM

J. T. Pivinski, American Water Works Service Co., Inc., Belleville, IL

M. Poutsma, Oak Ridge National Laboratory, Oak Ridge, TN

G. T. Reedy, Bourbonnais, IL

G. D. Robbins, Lockheed Martin Energy Systems, Inc., Oak Ridge, TN

A. T. Sherren, North Central College, Naperville, IL.

W. D. Shults, Oak Ridge, TN

J. E. Silliman, Milliken and Company, Spartanburg, SC

J. A. Sjoberg, ALMA, Santa Fe, NM

W. A. Spencer, Westinghouse Savannah River Company, Aiken, SC

J. Stokely, Oak Ridge National Laboratory, Oak Ridge, TN 
C. Stroup, Fluor Daniel Hanford Inc., Richland, WA

M. Tolbert, New Brunswick Laboratory, Argonne, IL

N. M. Trahey, National Institute of Standards \& Technology, Gaithersburg, MD

R. Villarreal, Los Alamos National Laboratory, Los Alamos, NM

W. J. Walsh, Health Research Institute, Naperville, IL

J. L. Warren, NFT, Inc., Lakewood, CO

S. Warren, USDOE, Office of Environmental Management, Germantown, MD

D. Wesolowski, U.S. Environmental Protection Agency, Chicago, IL

R. J. Wingender, Grayslake, IL

C. F. Wu, Westinghouse Electric Corporation, Carlsbad, NM 